\title{
Community Engagement Program Odapus (People with Lupus) 'My Lupus' Support Group Based in Wedomartani
}

\author{
Ayu Paramaiswari, ${ }^{1 *}$ Sri Awalia Febriana, ${ }^{2}$ Noor Asyiqah Sofia ${ }^{3}$ \\ 1Department of Rheumatology Division, Internal Medicine, Dr. Sardjito Central General Hospital, Yogyakarta, \\ Indonesia \\ ${ }^{2}$ Department of Dermatology and Venerology, Dr. Sardjito Central General Hospital, Yogyakarta, Indonesia \\ ${ }^{3}$ Department of Psychosomatic Division, Internal Medicine, Dr. Sardjito Central General Hospital, Yogyakarta, \\ Indonesia
}

Submitted: December 13 ${ }^{\text {th }}$ 2018; Revised: March 03 ${ }^{\text {rd }} 2021$; Accepted: March $04^{\text {th }} 2021$

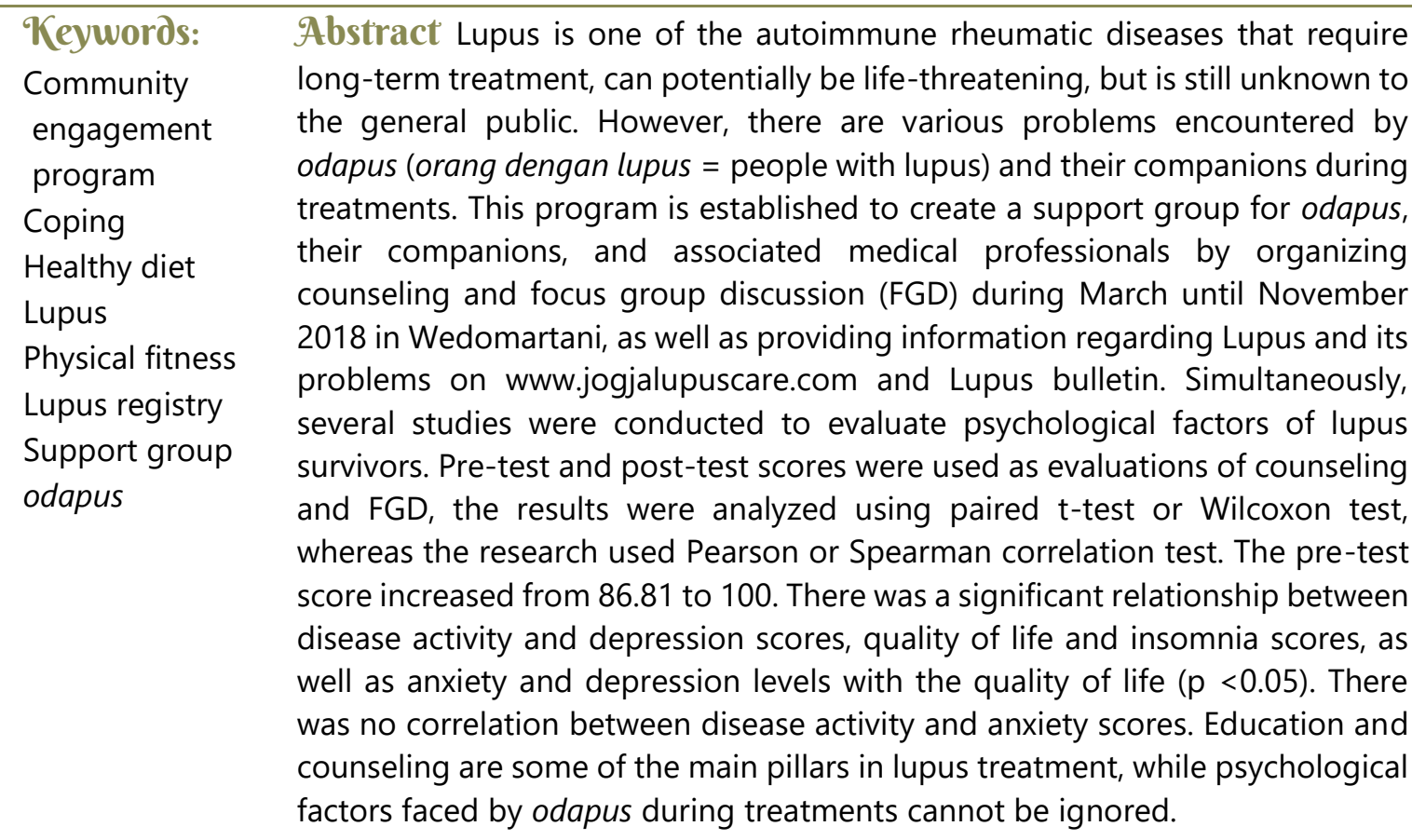

\section{INTRODUCTION}

Systemic lupus erythematosus (SLE), or lupus, is an autoimmune inflammatory disease that can involve multiple organs including skin, nervous system, kidney, hematology system, lung, and many others with various manifestations and levels of severity starting from mild to life-threatening. Incidence is 5,1 per 100.000 persons with nine-fold higher prevalence in females than males. Morbidity and mortality are high with five, ten, and twenty-year survival rates are $93-97 \%, 70-85 \%$, and
$53-64 \%$ respectively. The mortality rate is five times higher than the healthy population. Lupus often affects young and productive people (Perhimpunan Reumatologi Indonesia, 2011).

Various disease courses and high mortality rates due to this disease make it important to manage this disease very appropriately and comprehensively. Treatment and medication in lupus may take a long time or even become life-long to reach and maintain remission as well as to prevent disease flare (Perhimpunan Reumatologi Indonesia, 2011). There

ISSN 2460-9447 (print), ISSN 2541-5883 (online)

${ }^{*}$ Corresponding author: Ayu Paramaiswari

Rheumatology Division, Internal Medicine Department, Dr. Sardjito Central General Hospital, Yogyakarta Indonesia,

Jl. Kesehatan 1, Sekip Utara, Yogyakarta 55281, Indonesia

Email:ayu.paramaiswari@ugm.ac.id 
are several points in managing lupus, such as 1) education and counseling, 2) rehabilitation program, and 3 ) medication. These three points should be done together and simultaneously. Education and counseling are very important because they can support the success of the other two points (Perhimpunan Reumatologi Indonesia, 2011).

The objectives of this community program are to develop a support group that involves lupus patients (odapus), patients' spouses, and health care workers who will have appropriate knowledge and attitude so that they can overcome various problems the odapus often have and help to reach the goal of treatment done in hospital or clinic.

\section{PROBLEMS}

There are some issues faced by odapus while undergoing treatment, such as lack of knowledge about lupus itself, healthy diet, a tendency to develop anxiety and depression, skin, cosmetic, hair fall, even reproduction problems, and also long-term fatigue. In a previous study at Dr. Sardjito General Hospital Yogyakarta rheumatology clinic, among 30 subjects, $100 \%$ of odapus had depression in various levels $(30 \%$, minimal, $40 \%$, mild, $20 \%$ moderate, and $10 \%$ severe depression) and $33 \%$ had anxiety (23\% mild, $7 \%$ moderate, and $3 \%$ severe). Odapus would get a lot of advantages by developing and being supported by a support group to deal with problems and achieve therapy success (Maria, Paramaiswari, \& Sofia, 2018; Dorsey, Andresen, \& Moore, 2004; Mazzoni \& Cicignani, 2011; Raesfeld, 2017).

\section{METHOD}

\subsection{Problem solving}

The Odapus Community Engagement Program involves the odapus who lives in the Wedomartani area, from March to November 2018. Various activities were carried out to support the program, such as counseling, focus group discussion, website development, lupus bulletin, and numerous researches to assess the psychological factors among people affected with lupus.

\subsubsection{Counseling}

Counseling was given to odapus and their companions regarding lupus and its problems, skin health, healthy diet, fitness exercises, coping strategies, and social support. The counseling was carried out 4 times. The first was held on March 17, 2018 at the residents' homes in Wedomartani Sub-district, the second was on May 12 at the Ambarukmo Hotel Pavilion, the third was on July 7 at the Grand Cokro Hotel Lobby, and lastly on November 11 at the Hi-lab Laboratory Lobby. An open discussion was held at the end of each session to accommodate questions and other matters that have not been conveyed to odapus and their companions. A pretest and post-test were conducted to evaluate the understanding and knowledge of the counseling participants. The counseling covers the following points:

1. Explanation about lupus and its causes

2. Types of lupus and the nature of each type

3. Problems related to physical health: the benefits of exercise, especially concerning long-term use of corticosteroids such as osteoporosis; rest; diet education; use of assistive devices; skincare (avoiding sun and ultraviolet exposure, wearing sunscreen, umbrellas or hats), contraception, and attempts to avoid and treat infections

4. Introduction of topics with psychological aspects: self-understanding, ways to deal with prolonged fatigue, emotional stress, psychological trauma, problems related to family and work, overcoming pain

5. Use of drugs such as type, dose, and duration of administration, whether or not vitamin and mineral supplementation is needed

6. Description of where the patient can get precise and accurate information about lupus, support group, lupus foundations, and many others

\subsubsection{Focus group discussion}

Focus group discussion (FGD) is a qualitative approach to understanding the problem. This FGD was held on 11 November 2018 and took place in the Hi-lab Laboratory Lobby. Odapus and their companions were divided into small groups of 8-12 people together with a moderator/facilitator and observer/note-taker. The discussion began with an introduction from the facilitator about common problems encountered by odapus and their companions, followed by opinions/brainstorming on these issues from each participant as well as the suggestions that can be made to solve them. It could be from reading material/literature and also from the personal experiences of odapus and their companions.

\subsubsection{Website development}

Searching for information through the internet and internet search engines is one of the simplest, quickest, and cheapest methods. However, the quality of internet searches is limited by a large amount of information and sometimes without specific references, so that odapus and their companions need an accurate and reliable information portal. Since 2018, the website www.jogjalupuscare.com has provided articles written by health professionals, such as doctors, psychologists, nurses, nutritionists, physiotherapists, as well as odapus, to share literature-based and personal 
experience in their attempts to overcome lupus. There is a section for doctor's questions and answers, lupus registries, information on where to seek treatment, information for the public and medical professional on lupus-related symposiums or conferences.

\subsubsection{Development of a Lupus Bulletin}

The lupus bulletin will enclose numerous articles written by health professionals such as doctors, nurses, nutritionists, physiotherapists, and odapus. The published articles provide various features about lupus and things that can be done to solve the problems encountered by odapus and his companions. The bulletin will be distributed to odapus at the lupusthemed events.

\subsubsection{Research}

Several studies were conducted on the odapus population in Wedomartani from March to November 2018, particularly to assess the relationship of psychological factors with lupus disease activity. The study was performed on 30 participants with SLE based on the 1997 ACR criteria who were willing to participate in the study. Odapus who were hospitalized or had cerebral lupus were excluded from the study. Descriptive-analytic research was carried out using a cross-sectional method.

The studies which have been performed include:

1. The Relationship between Disease Activity and Depression and Anxiety Score in Systemic Lupus Erythematosus Patients (Maria, Paramaiswari, \& Sofia, 2018)

2. The Relationship between Anxiety Level and Quality of Life in Systemic Lupus Erythematosus (Prabowo, Paramaiswari, \& Sofia, 2018)

3. The Relationship between Depression Level and Quality of Life in Systemic Lupus Erythematosus (SLE) Patients (Khairina, Paramaiswari, \& Sofia, 2018)

4. The Relationship between Disease Activity and Quality of Life in Systemic Lupus Erythematosus Patients (Theresia, Paramaiswari, \& Sofia, 2018)

5. The Relationship between Disease Activity and Insomnia Score in Systemic Lupus Erythematosus Patients (Zagoto, Paramaiswari, \& Sofia, 2018)

Research on the relationship of disease activity was measured using the Mexican Systemic Lupus Erythematosus Disease Activity (MEX-SLEDAI), while the depression score was measured using the Patient Health Questionnaire-9 (PHQ-9). Anxiety scores were assessed using the General Anxiety Disorder-7 (GAD-7) and Quality of Life using the SLEQuality of Life (SLE-QOL) score. Lastly, the insomnia Score used the Insomnia Severity Index (ISI) measurement tool.

\subsection{How to analyze results}

Data analysis will be performed using SPSS 20.0. The pre-test and post-test results from the counseling program were analyzed using a paired t-test or Wilcoxon test if the parametric test criteria were not met. A p-value $<0.05$ was considered statistically significant. The research data was analyzed using the Pearson and Spearman correlation test (if it did not meet the criteria of the parametric test) to determine the strength of the relationship between independent and dependent variables. The $\mathrm{p}$-value $<0.05$ was considered statistically significant with $\mathrm{r}$ correlation $<0.3$ indicating a weak relationship, 0.3-0.49 showing a moderate relationship, 0.50-0.69 showing a strong relationship, while $>0.7$ showing a very strong relationship

\section{RESULT AND DISCUSSION}

\section{1 Subject characteristics}

There were 44 odapus who participated in counseling and focus group discussions (FGD), consisting of 29 $(65.9 \%)$ women and $15(34.1 \%)$ men (Table 1). The population included participants from 10-49 years old, with $50 \%$ of the population were 30-39 years old, $34,1 \%$ were $20-29$ years old, $11,4 \%$ were $40-49$ years old, and 4,5\% were 10-19 years old. Most of the participant were senior high school dan university graduates (40,9\% and $43,2 \%$, respectively).

Table 1. Subject characteristics

\begin{tabular}{lcc}
\hline $\begin{array}{l}\text { Subject characteristic } \\
\text { Number of subjects }\end{array}$ & $\mathrm{n}$ & $\%$ \\
Sex & & \\
$\quad$ Male & 15 & $34.1 \%$ \\
$\quad$ Female & 29 & $65.9 \%$ \\
Age: & & \\
10-19 years old & 2 & $4.5 \%$ \\
20-29 years old & 15 & $34.1 \%$ \\
30-39 years old & 22 & $50 \%$ \\
40-49 years old & 5 & $11.4 \%$ \\
Latest education & & \\
Primary school & 3 & $6.8 \%$ \\
Junior high school & 4 & $9.1 \%$ \\
Senior high school & 18 & $40.9 \%$ \\
University & 19 & $43.2 \%$ \\
& & \\
\hline
\end{tabular}

(Maria, Paramaiswari, \& Sofia, 2018)

\subsection{Knowledge of lupus}

The average odapus pretest score improved from 86.81 to 100 after counseling and FGD $(\mathrm{p}=0.00)$ (Table 2). In the pre-test, the least correct answers were found in question 10 (34\%), question 13 (64\%), and question 17 (80\%). All participants were able to answer the question correctly in the first, third, eighth, ninth, and eighteenth questions. There is an increase in scores 
from all question items, where all post-test questions can be answered correctly (100\%).

Table 2. Pre-test and post-test results

\begin{tabular}{|c|c|c|c|}
\hline Question & $\begin{array}{l}\text { Pre-test } \\
\mathrm{N}=44 \\
\text { Correct } \\
\text { answer= } \\
\mathrm{n}(\%)\end{array}$ & $\begin{array}{l}\text { Post-test } \\
\mathrm{N}=44 \\
\text { Correct } \\
\text { answer } \\
\mathrm{n}(\%)\end{array}$ & $p$-value \\
\hline Question 1 & $44(100)$ & $44(100)$ & \\
\hline Question 2 & 41(93) & $44(100)$ & \\
\hline Question 3 & $44(100)$ & $44(100)$ & \\
\hline Question 4 & $38(86)$ & 44 (100) & \\
\hline Question 5 & $38(86)$ & 44 (100) & \\
\hline Question 6 & 43(98) & 44 (100) & \\
\hline Question 7 & $36(82)$ & $44(100)$ & \\
\hline Question 8 & $44(100)$ & 44 (100) & \\
\hline Question 9 & $44(100)$ & 44 (100) & \\
\hline Question 10 & $15(34)$ & 44 (100) & \\
\hline Question 11 & $37(84)$ & $44(100)$ & \\
\hline Question 12 & 43(98) & 44 (100) & \\
\hline Question 13 & $28(64)$ & 44 (100) & \\
\hline Question 14 & 43(98) & 44 (100) & \\
\hline Question 15 & 43(98) & 44 (100) & \\
\hline Question 16 & 43(98) & 44 (100) & \\
\hline Question 17 & $35(80)$ & 44 (100) & \\
\hline Question 18 & $44(100)$ & $44(100)$ & \\
\hline Question 19 & 41(93) & $44(100)$ & \\
\hline Question 20 & $42(95)$ & 44 (100) & \\
\hline Mean score & 86.8 & 100 & 0.00 \\
\hline
\end{tabular}

The www.jogjalupuscare.com website has been developed and operated since 2018. The website consists of a home page with links to each sub-category, as well as brief reviews of new articles and columns of works, events and agendas (Figure 1-4).

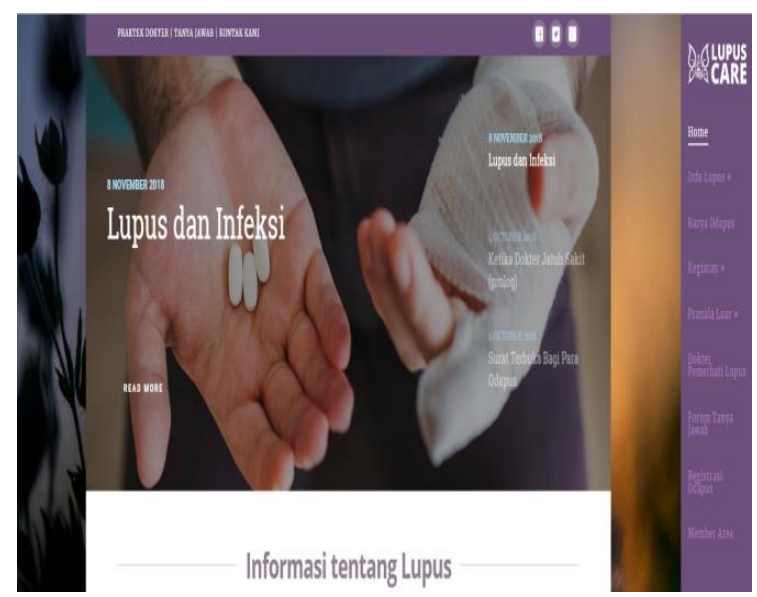

Figure 1. www.jogjalupuscare.com home website
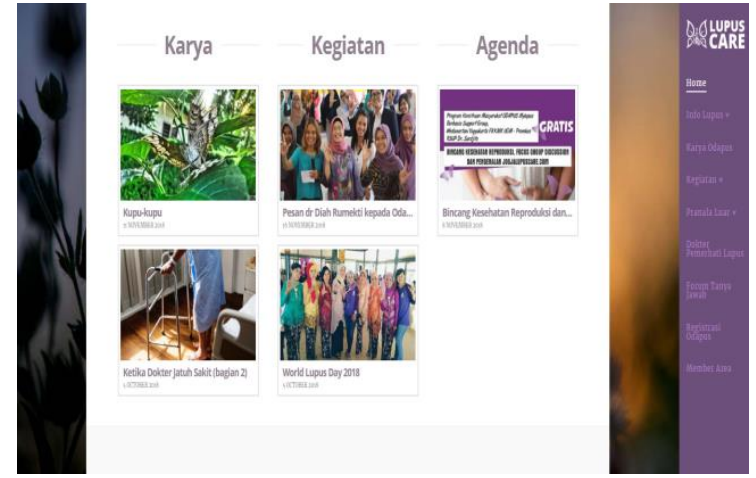

Figure 2. Links to odapus' work, activities and agenda on the www.jogjalupuscare.com website

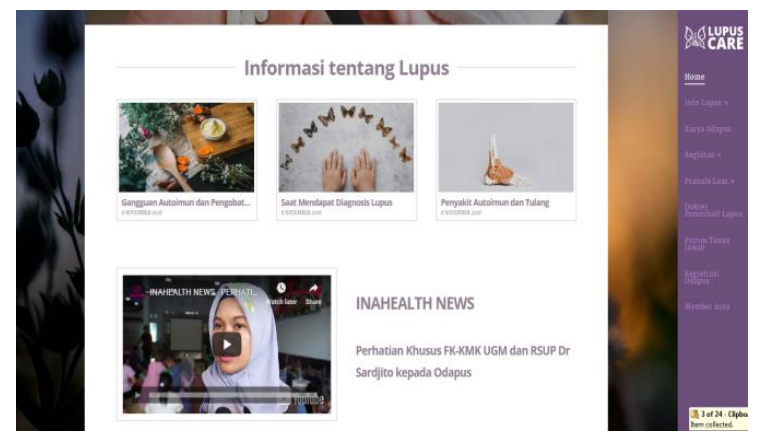

Figure 3. Lupus information page on the www.jogjalupuscare.com homepage

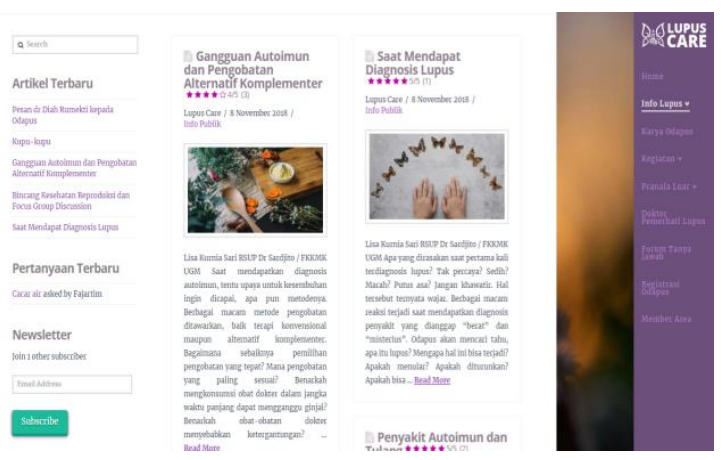

Figure 4. Lupus educational article page for medical community, people with HIV/AIDS and companions.

Sub-categories that can be accessed include: 1) lupus information, containing several different lupusrelated articles, its problems and treatments for medical professional, odapus companions, and odapus itself; 2) odapus works, comprising odapus' numerous works and writings; 3 ) events, including information on the activities of odapus, seminars/symposiums, and activities schedule/calendar; 4) external links to various supportive sites, such as various domestic and international organizations, rheumatology associations, health services, and BPJS; 5) doctors who observe lupus; 6) forums for questions and answers; 7) odapus registration; and 8) area of membership. There is also a link to the practice of doctors who have a special interest in treating lupus patients and information about contacting the website administrator via our contact link. 


\subsection{The relationship between disease activity and depression and anxiety score in patients with SLE}

The study on the relationship of disease activity (measured using MEX-SLEDAI) with depression score (PHQ-9) and anxiety (GAD-7) in systemic lupus erythematosus patients at RSUP DR Sardjito Yogyakarta involving 30 patients with SLE showed that depression occurred in $100 \%$ of lupus patients, specifically $30 \%$ had minimal depression, $40 \%$ mild depression, $20 \%$ moderate depression, and 10\% major depression. The incidence of anxiety was found to be $33.33 \%$ of patients with lupus, where $23.33 \%$ had mild anxiety, $6.67 \%$ moderate anxiety, and $3.33 \%$ severe anxiety.
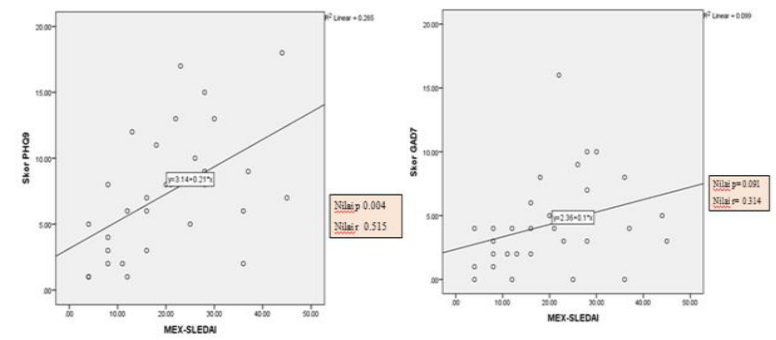

Figure 5. Scatter plot of correlation between MEX-SLEDAI with PHQ-9 and GAD-7

The correlation test result between disease activity and depression score was $\mathrm{p}=0.004$ and $\mathrm{r}=0.515$, while the correlation test result between disease activity and anxiety scores was found to be $p=0.091$ and $r=0.314$ (Figure 5). A significant correlation was found between disease activity and depression scores with moderate correlation strength, whereas there was no correlation between disease activity and anxiety scores (Maria, Paramaiswari, \& Sofia, 2018).

\subsection{Relationship between the level of anxiety and quality of life in patients with SLE}

The study on the relationship between anxiety level (GAD-7) and quality of life (SLE-QOL) in SLE patients at RSUP DR Sardjito Yogyakarta involving 30 patients with SLE showed a significant correlation $(\mathrm{p}=$ 0.000019) with a strong correlation strength $(r=0.697)$ between GAD-7 and SLE-QOL (Figure 6) (Prabowo, Paramaiswari, \& Sofia, 2018).

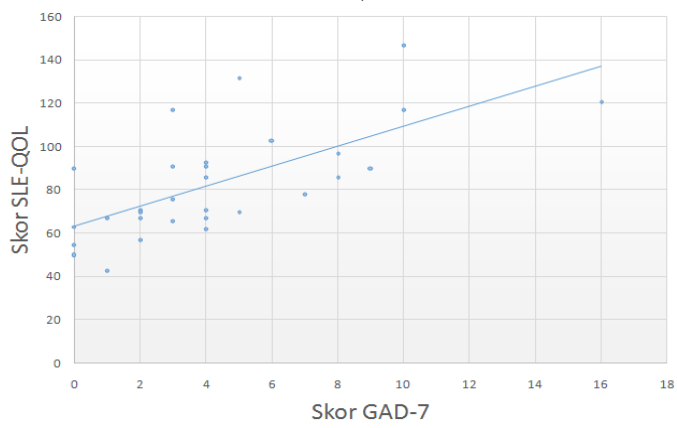

Figure 6. Scatter plot of correlation between GAD-7 and SLEQOL

\subsection{The relationship between the depression level and the quality of life in patients with SLE}

The study on the relationship between depression level (PHQ-9) and quality of life (SLE-QOL) in SLE patients at RSUP DR Sardjito Yogyakarta, including 30 SLE patients, showed a significant correlation $(\mathrm{p}=0.009)$ with a strong correlation $(\mathrm{r}=0.783)$ between PHQ-9 and SLE-QOL (Figure 7) (Khairina, Paramaiswari, \& Sofia, 2018).

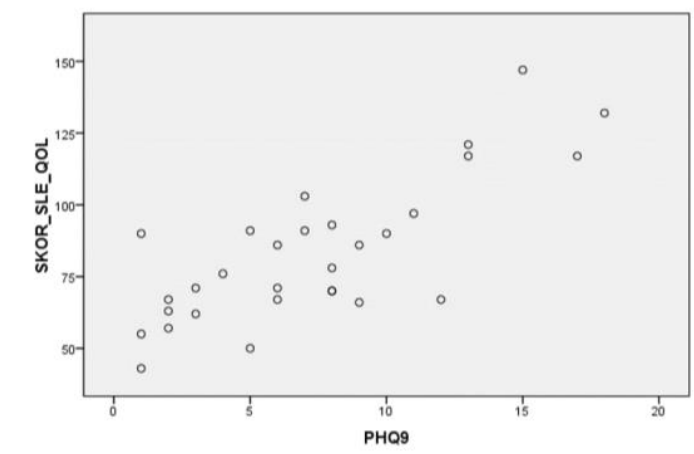

Figure 7. Scatter plot of correlation between PHQ-9 and SLE$\mathrm{QOL}$

\subsection{Relationship between disease activity and quality of life in patients with SLE}

The study on the relationship between disease activity (MEX-SLEDAI) and quality of life (SLE-QOL) in RSUP DR Sardjito Yogyakarta among 30 SLE patients showed a significant correlation $(\mathrm{p}=0.017)$ with moderate correlation intensity $(\mathrm{r}=0.432)$ between MEX-SLEDAI and SLE-QOL (Figure 8) (Theresia, Paramaiswari, \& Sofia, 2018).

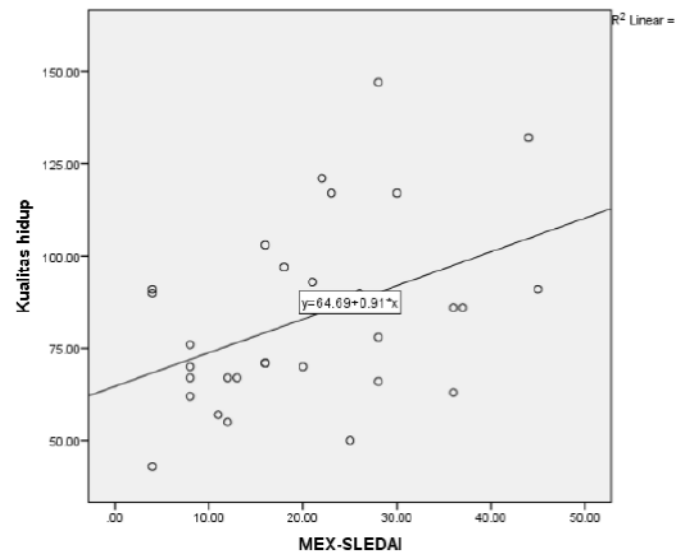

Figure 8. Scatter plot of correlation between MEX-SLEDAI and SLE-QOL

\subsection{Relationship between disease activity and insomnia score in SLE Patients}

The study on the relationship between disease activity (MEX-SLEDAI) and Insomnia Severity Index (ISI) in SLE patients at RSUP Dr. Sardjito Yogyakarta involving 30 patients with SLE showed a significant correlation $(\mathrm{p}=0.03)$ between MEX-SLEDAI and ISI with moderate correlation strength $(r=0.397)$ (Figure 9) (Zagoto, Paramaiswari, \& Sofia, 2018). 


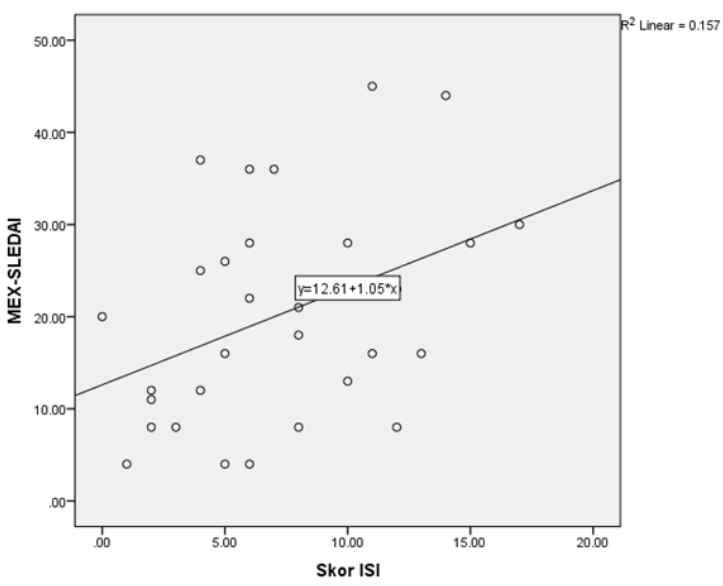

Figure 9. Scatter plot of correlation between MEX-SLEDAI and ISI

\section{CONCLUSION}

Education and counseling are some of the pillars that will facilitate the success of the rehabilitation program and medical care in the treatment of lupus. It is important since lupus treatment generally takes a long time and odapus tend to experience various physical and psychological issues that affect the treatment's effectiveness. Support groups play an important role and are known to assist odapus to deal with different lupus-related issues.

The counseling and FGD conducted at the Odapus-based Community Engagement Program in Wedomartani have significantly enhanced the knowledge and understanding of Odapus and their companions and are expected to support the success of Odapus medical and rehabilitation programs. The website www.jogjalupuscare.com and the Lupus Bulletin are expected to be an accurate, affordable, and easily accessible tool for odapus and their companions to obtain reliable information containing various writings and works by both health professionals and odapus. This media can also play a role as part of the support group system for odapus as it also provides space for interaction among odapus and their companions through question-and-answer forums and with health professionals such as doctors so that the role of the support group is not limited to face-to-face meetings alone.

The studies conducted showed a significant correlation between disease activity and depression, anxiety levels and quality of life, depression levels and quality of life, disease activity and quality of life, as well as disease activity and insomnia scores. This reveals that instruments for psychological condition evaluation such as PHQ-9 for depression, GAD-7 for anxiety, SLE-QOL for quality of life, and ISI for insomnia may be used as a method to determine odapus' psychological problems.

The Support Group-based Community Engagement Program (PKM) in Wedomartani will improve the knowledge and understanding of odapus and their companions constructively and sustainably so that it is hoped to enhance the success of the hospital's lupus treatment.

\section{ACKNOWLEDGMENT}

We thank Mrs Lucia Tyas (Lupus Warrior), Mrs Ian Sofyan (Sahabat Cempluk), Mr Alfred Zakaria (RELIRelawan Lupus Indonesia), Mrs Sri Rahayu, S.Kep, NS (Head of Health Promotion Division, Dr Sardjito Central General Hospital, Yogyakarta) for the support during this study. We are grateful to all participants, volunteers, doctors, nurses, psychologists, and administrative staff involved in the program for their valuable contributions to this study.

\section{CONFLICT OF INTERESTS}

This research is financed by Ministry of Research, Technology and Higher Education. We did not receive any other support grant for the research. The authors disclose no conflicts.

\section{REFERENCES}

Dorsey, R. R., Andresen, E. M., \& Moore, T. L. (2004). Health-related quality of life and support group attendance for patients with systemic lupus erythematosus. Journal of clinical rheumatology: practical reports on rheumatic \& musculoskeletal diseases, 10(1), 6-9. DOI: https://doi.org/10.1097/01.rhu.0000111311.384 07.15

Kharinina, A., Paramaiswari, A., Sofia, N.A. (2018). Hubungan Tingkat Depresi dengan Kualitas Hidup pada Pasien Lupus Eritematosus Sistemik (LES) di RSUP DR Sarjito Yogyakarta. Thesis. Universitas Gadjah Mada.

Lupus and the Benefits Of Joining Support Groups. (n.d.). Retrieved December 12, 2018, from https://lupusnewstoday.com/2017/09/01/lupusbenefits-of-support-groups/

Maria, A.S., Paramaiswari, A., \& Sofia, N.A. (2018). Hubungan Aktivitas Penyakit dengan skor Depresi dan Ansietas Pada PAsien Lupus Eritematosis Sistemik di RSUP DR. Sardjito Yogyakarta. Thesis. Universitas Gadjah Mada.

Mazzoni, D., \& Cicognani, E. (2011). Social support and health in patients with systemic lupus erythematosus: a literature review. Lupus, 20(11), 1117-1125. DOI: https://doi.org/10.1177/0961203311412994

Prabowo, A., Paramaiswari, A., Sofia, N.A. (2018). Hubungan Tingkat Ansietas dengan Kualitas Hidup pada Pasien Lupus Eritematosus Sistemik di RSUP DR Sarjito Yogyakarta. Universitas Gadjah Mada. Thesis. Universitas Gadjah Mada. 
Sumariyono, Kalim, H., Setyohadi, B., Hidayat, R., Najiman, Hamijoyo, L., Wijaya, L. K., Rahmadi, A. R., Wahono, C. S., Rahmawati, L. D., Nurudhin, A., Wibowo, S. A. K., \& Arianne, A. (2019). Diagnosis dan Pengelolaan Lupus Eritematosus Sistemik.pdf (Revisi dar). Perhimpunan Reumatologi Indonesia.

Theresia, A.P.D.S., Prabowo, A., \& Sofia, N.A. (2018). Hubungan Aktivitas Penyakit dengan Kualitas Hidup Pasien Lupus Eritematosus Sistemik di RSUP DR Sarjito Yogyakarta. Thesis. Universitas Gadjah Mada.

Zagoto, A., Prabowo, A., \& Sofia, N.A. (2018). Hubungan Aktivitas Penyakit dengan Skor Insomnia pada Pasien Lupus Eritematosus Sistemik di RSUP DR Sarjito Yogyakarta. Thesis. Universitas Gadjah Mada. 